QUALIDADE DE VIDA NA EMPRESA - ORGANIZANDO PELA AUSÊNCIA.

OLIVEIRA, E. TOYOTISMO NO BRASIL: DESENCANTAMENTO DA FÁBRICA, ENVOLVIMENTO E RESISTENCIA.

SÃO PAULO: EXPRESSÃO POPULAR, 2004.

Aguinaldo Gonçalves

QUALITY OF LIFE IN THE COMPANY - ORGANIZING FOR THE ABSENCE.

OLIVEIRA. E. TOYOTISMO IN BRAZIL: DESENCANTAMENTO OF THE FACTORY, INVOLVEMENT AND RESISTANCE.

SAO PAULO: POPULAR EXPRESSION, 2004.

Aguinaldo Gonçalves

Nestes tempos contemporâneos em que se conta com o consenso firmemente construído de que concepções e práticas se fulcram em interlocução entre categorias e realidades como multiprofissionalidade e transversalidade, integração e promoção, debate e tematização, inclusão e proposição, reflexão e intervenção, obras como estas vêm aportar contribuições basilares não só para a formação mas até para a atualização dos profissionais com atuação na área. Embora se trate de texto não restritamente acadêmico, encerrando clara dimensão de esclarecimento e divulgação, nem por isso foge, desde a concepção à formulação, às clássicas exigências do rigor científico.

Assim posta do ponto de vista metodológico, quanto à essência de seu objeto de estudo retoma as características ideológico-estruturais do estabelecimento empresarial capitalista de nossos dias, focando no segundo elemento da trilogia fordismo-toyotismo-volvismo, metáfora pela qual se busca modelar a identidade dos procedimentos das organizações pela analogia com os três conjuntos de práticas conotadas pelas corporações do mundo automobilístico que os representariam.

Neste contexto, o primeiro paradigma mencionado sob a raiz da empresa norte-americana se tipifica pelo “pioneirismo" da produção em série, conhecido pela caricatura cáustica de Charles Chaplin no filme dos Tempos Modernos: trata-se da execução atomizada e alienada de gestos isolados e mecânicos, em que o trabalhador não empreende a construção de algo, mas cumpre tarefas cuja totalização e resultados desconhece. Por extensão, a relação que mantém com a sociedade é a da propaganda e do consumerismo.

Sob o signo da marca do tigre asiático, agrupa-se série de recursos expressos pela primeira vez de forma organizada por Taiichi Ohno, engenheiro pertencente à mesma. “ A partir da importação de técnicas de 
gestão de estoques de supermercados estadunidenses (...), integrou as técnicas do saber-fazer do ramo têxtil - setor tradicional de atividade da Toyota - que permitiram a um operário dominar várias máquinas (...)", superando, assim, o "rendimento do trabalho vivo" do modelo ocidental inspirador : desse modo, foi possível expurgar das linhas de produção algo como um milhão de demissões, às custas da tensão máxima dos protagonistas, pela elevação do desgaste da força de trabalho até níveis considerados desumanos! Nessas oportunidades de acionar o " facão", numa cascata de terceirizações, os empregados mais "fidelizados" têm mantidos seus vínculos pela prestação de serviços numa subsidiária de primeira ordem; se necessário, migram para uma de segunda e assim sucessivamente, de sorte que se mantém a imagem pública de que aqueles que se subordinam pacificamente a seus patrões, nunca são por estes abandonados. A autora é bastante clara ao indicar que não se trata, portanto, de nenhum ingênuo culto ético-cultural, mas sim da execução deste às custas do recurso coletivo administrado pela rigidez do lucro.

Para completar o quadro, o volvismo corresponderia ao estágio mais evoluído do ajuste em que a indústria se desdobra para a comunidade, não mais sobretudo pela publicidade e consumo como no primeiro caso, nem pela pseudo vinculação vitalícia empregado -empregador, mas pelos investimentos da empresa no amparo, promoção e desenvolvimento nos extra-muros da escola, da igreja, dos equipamentos sociais. Essa imagem de generosidade e respeito humanos significam, na realidade, ampliação do espaço político da organização sobre a vida dos cidadãos, fortalecendo, no quotidiano, sua força de influência privada e lucrativa sobre políticas públicas de um Estado que se retrai enquanto tal (Paoli, 2002). Segundo alguns (v.g. Gonçalves, 2005), aí estaria a origem daquilo que hoje se celebra e comemora como Responsabilidade Social Corporativa, considerada, portanto, mui legitimamente como "lobo em pele de cordeiro".

Em termos de composição redacional, o texto se organiza a partir de três segmentos, que, embora de entendimento autônomo, são claramente complementares. No primeiro, o toyotismo como processo de trabalho é recuperado em suas bases no país de origem; a seguir, retoma-se sua aculturação à brasileira, para, ao final, proceder-se diretamente ao corte ocorrido com a planta da firma em Indaiatuba, cidade do interior do Estado de São Paulo, situada na região metropolitana de Campinas. São elementos que constroem síntese do mestrado e doutorado da autora, defendidos na Unicamp, sob a orientação do Prof. Ricardo Antunes, intelectual cuja menção dispensa apresentação, dada sua militância acadêmica na convivência e compreensão do Mundo do Trabalho . 
O foco central está posto na recuperação da trajetória da corporação em nosso país, pois vale a pena conhecê-la com certa profundidade para se ter acesso a uma adaptação bem sucedida do ruim para o pior, ao menos em termos de Saúde do Trabalhador! Mesmo antes de iniciar atividades de forma mais decidida no território brasileiro, seus executivos pioneiros trouxeram, na valise técnica, conjunto não reduzido de ferramentas bastante perversas já validadas na metrópole. O destaque para algumas delas, procedido a seguir, a partir da minudicente recuperação original, permite avaliar-lhe a identidade:

i) a já citada proteção patronal vitalícia, em que o trabalhador circunscreve o âmbito de suas expectativas e possibilidades apenas à sobrevida na colocação que detém, em troca de tudo o mais, pois, se em outra empresa, deverá iniciar novamente no piso da escala salarial, com redução do poder aquisitivo e perda da aposentadoria;

ii) implementação de "eficiente" sistema de sugestões de melhoras contínuas por parte dos empregados, dirigidas ao aumento da produtividade e do lucro do capital: "serve para indicar os trabalhadores desinteressados e para localizar pessoal em excesso; sobrecarrega os operadores com novas tarefas; diminui o tempo de execução e possibilita pressões de toda ordem" ( OLIVEIRA, 2004, p. 154);

iii) o gerenciamento participativo, i.e., “ instrumental teórico de produção de sublimações das emoções e sentimentos de pertencimento à empresa";

iv) os grupos de autogestão operária, em que os executores determinam as elevações de seus recordes de rendimento :quando elas começam a aumentar o número de acidentes e mortes, ninguém pode acusar a empresa, porque a decisão foi deles!;

v) as extremamente eloqüentes campanhas zero-defeito;

vi) o sindicato-empresa, isto é, o órgão classista, à medida que se torna braço operativo para formação de opiniões e convencimentos favoráveis ao empresário, participa na seleção e ascensão de empregos: trata-se, nos termos relatados, de " proteger a empresa para proteger nossa vida";

vii) a produção enxuta, pela qual se contrata " contingente de trabalhadoras jovens, sem prática em fábrica, mas com habilidade manual finíssima para montar pequenas peças de componentes eletrônicos, em movimentos rápidos, 
repetidos, precisos e entrecortados, como um pequeno robô" (OLIVEIRA, 2004, p. 71);

viii) o trabalhador colaborador, forma produtiva flexibilizada e desregulamentada, em que o empregado aprende diferentes processos para poder ser deslocado para várias tarefas, de acordo com a necessidade da produção diária.

$\mathrm{Na}$ aplicação, porém, tais estratégias ainda se superaram, pela implantação de outras mais singulares, como a escolha do local de construção da fábrica a distância adequada dos centros metropolitanos tradicionais: pequena o suficiente para não se afastar dos círculos e das decisões e grande o necessário para não permitir contaminação com informações das vitórias trabalhistas acumuladas por movimentos sociais pregressos.

Tudo isto considerado - e certamente muito mais! - , pode-se concluir com a advertência e esclarecimento da autora que a fábrica moderna ao estilo toyotista é tão mais cruel, selvagem e violenta que torna amena a outra, aquela à antiga, legitimamente fordista .

Referências

GONÇALVES, A. Introduzindo responsabilidade corporativa: responsabilidade ou corporativa? . In: GONÇALVES, A.; GUTIERREZ, G. L.; VILARTA, R. (Org.). Gestão da qualidade de vida na empresa. Campinas: PREAC/UNICAMP, 2005. p. 23-31.

PAOLI, M. C. Empresas e responsabilidade social: os enredamentos da cidadania no Brasil. In: SANTOS, B. S Democratizar a democracia. Rio de Janeiro: Civilização Brasileira, 2002. p. 373-418. 


\section{Aguinaldo Gonçalves}

Faculdade de Educação Física/UNICAMP

\section{Referência do artigo}

ABNT

GONÇALVES, A. Qualidade de vida na empresa - organizando pela ausência.

Oliveira, E. toyotismo no brasil: desencantamento da fábrica, envolvimento e resistência.

São Paulo: expressão popular, 2004. Conexões, v. 5, n.2, p. 129-133, 2007.

\section{APA}

Gonçalves, A. (2007). Qualidade de vida na empresa - organizando pela ausência.

Oliveira, E. toyotismo no brasil: desencantamento da fábrica, envolvimento e resistência.

São Paulo: expressão popular, 2004. Conexões, 5(2), 129-133.

\section{VANCOUVER}

Gonçalves A, Qualidade de vida na empresa - organizando pela ausência.

Oliveira, E. toyotismo no brasil: desencantamento da fábrica, envolvimento e resistência.

São Paulo: expressão popular, 2004. Conexões; 5(2): 129-133. 